\title{
The youth vote in the 2021 Local Government Elections in South Africa
}

\section{Martin Bekker and Carin Runciman}

\begin{abstract}
Few youth (including would-be first-time voters) registered to vote in the 2021 South African Local Government Elections, and among those registered, fewer still came out to vote on election day. Of the young voters in our sample (those aged 18-34 years) $42 \%$ self-reported having voted for the ANC, $25 \%$ for the DA, and 9\% for the EFF. This means that, among young voters who cast a ballot, support for the ANC is almost double that for the DA, and support for the DA is well over double support for the EFF. Despite low support for the EFF among young voters, the youth nonetheless represent the EFF's primary support base. Sixty percent of the EFF's voters were under the age of 37 . Voting trends for the main political parties by young voters follow generally expected patterns of class and racialized configurations of support. Young Black African voters mostly voted for the ANC while White, Coloured and Indian and Asian young voters mostly voted for the DA. Lower income groups had higher share of support for the ANC and the DA drew more of its votes from higher income groups. EFF supporters drew predominately their support from either end of the income scale, with their support concentrated in the lowest and highest income brackets. The explanations that young people gave for not voting were not distinct from that of older age cohorts. The three most common reasons were individual barriers (33\%), such as not being in their registered ward on Election day, being at work, or saying they were simply 'too busy' to vote; administrative barriers (25\%), such as not being registered to vote and being uninterested and disillusioned (17\%). Youth voters display a non-negligible degree of voter fluidity, switching between voting and abstention, and in switching party support between elections. This mirrors similar trends that emerged in the wider electorate.
\end{abstract}




\section{Introduction}

The 2021 local government election continued a trend of low and declining turnout amongst young and first-time voters. Of the nearly 1.8 million 18-19 year olds who were eligible to vote in the last election, $90 \%$ did not register. Similarly, less than $20 \%$ of the population aged 20 to 35 registered to vote, in contrast to over $90 \%$ of the population aged 40 .

The voter participation of young people - or lack thereof - has been of concern and interest for some time, especially, as the 'born-free' generation has become eligible to vote. This report examines the decisions to vote or not to vote made by young voters in five metropolitan municipalities: City of Johannesburg, City of Tshwane, eThekwini, City of Cape Town, and Nelson Mandela Bay; the findings presented in this report are representative of the South African population within these municipalities.2 Our findings are based on a telephone survey of 3,905 residents who were eligible to vote in the 2021 local government elections, conducted in the days immediately following the election. Of that sample, 1,531 participants were aged between 18 and 35 - the ages that are typically defined as 'youth' in South Africa. It is on this sub-set of the overall sample that this report analyses.

\section{Youth voter participation}

Figure 1 provides an analysis of voter participation by age. It must be noted that our survey sample over-represents voters compared to the known voter turnout. Despite this skew, the graph demonstrates that the younger the respondent, the less likely they are to have voted. This confirms the general trends in what is known about youth voter participation.

Figure 1: Voting participation by age cohorts in the 2021 Local Government Election (reporting the University of Johannesburg Centre for Social Change 2021 Election Survey data)

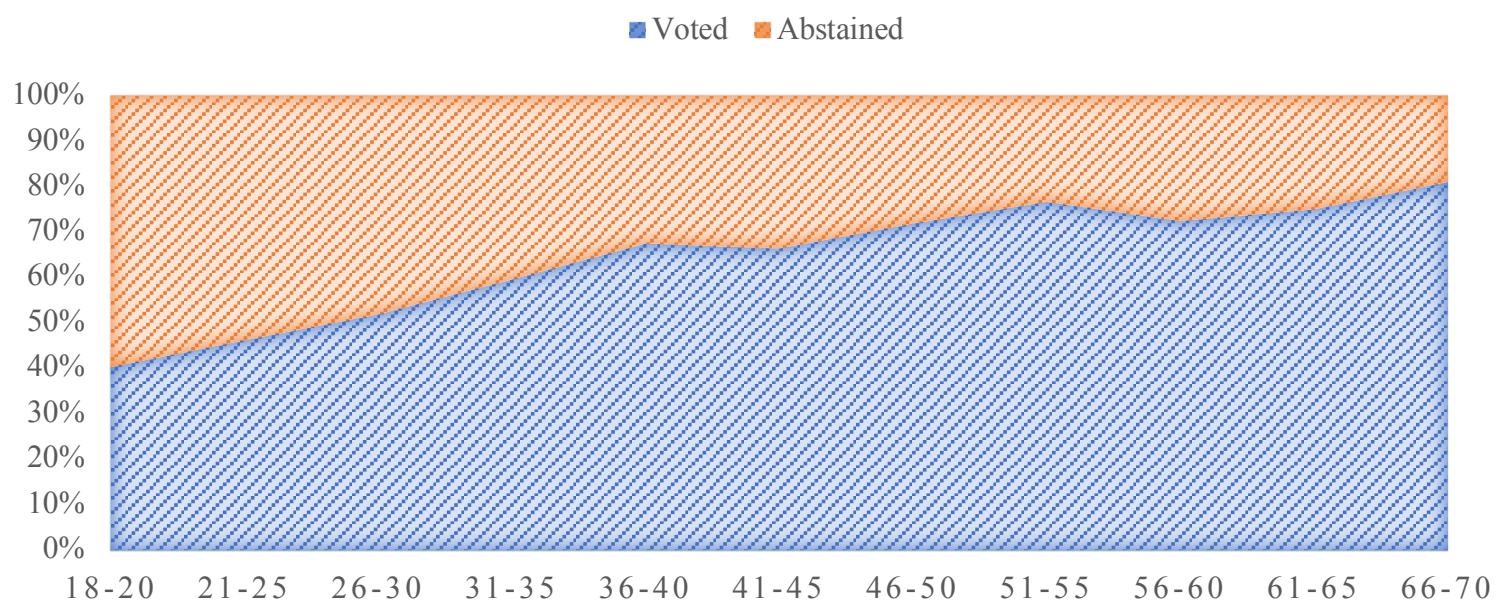




\section{Youth voting decisions}

Table 1 provides an analysis of party support in the 2021 LGE by different age cohorts. Amongst the youngest cohort (aged 18-20) we see that the ANC was the most popular party, followed by the DA and then the EFF. As in previous elections, the EFF drew most of their support from younger voters. Table 1, below, reveals that $13 \%$ of first-time voters voted for the EFF, its popularity dropping by roughly two percentage points among every additional ten-year cohort. The table also illustrates that support for the DA is largely consistent across age, while they enjoy their highest levels of support amongst the oldest age cohorts.

Table 1: Party voted for in the 2021 LGE, by age cohort (illustrated using unweighted University of Johannesburg Centre for Social Change 2021 Election Survey data, $\mathrm{N}=2,617$ )

\begin{tabular}{ccccc}
\hline & \multicolumn{4}{c}{ Percentage of vote } \\
\cline { 2 - 5 } Ages & EFF & ANC & DA & Other \\
\hline $18-20$ & 13 & 59 & 28 & 0 \\
$21-25$ & 12 & 55 & 17 & 16 \\
$26-30$ & 9 & 37 & 28 & 26 \\
$31-35$ & 8 & 43 & 27 & 22 \\
$36-40$ & 8 & 42 & 29 & 20 \\
$41-45$ & 7 & 41 & 27 & 25 \\
$46-50$ & 6 & 43 & 31 & 20 \\
$51-55$ & 2 & 40 & 34 & 24 \\
$56-60$ & 2 & 41 & 46 & 12 \\
$61-65$ & 3 & 41 & 34 & 21 \\
$66-70$ & 0 & 32 & 51 & 17 \\
$71-75$ & 2 & 15 & 64 & 19 \\
\hline
\end{tabular}

Note: The above table report proportion of votes, omitting refusals $(\mathrm{N}=478)$, where, in the cohorts above 21-25, each returned a percentage above $38 \%$ of respondents choosing not to divulge how they voted.

Figure 2, below confirms the EFF's youthful base, while simultaneously illustrating its minor command of the youth vote, as well as limited among the broader electorate. In contrast, the ANC does well to capture the youth vote, and is also popular across the spectrum of voting-eligible ages. Once more, we note the DA's most robust support, proportionally speaking, appears to be among older cohorts.

Notwithstanding the above, when the youth vote is analysed by a selection of socio-demographic factors, a clearer profile of the youth vote emerges. As Table 2 demonstrates, the youth vote follows the expected patterns of racialized support for the three main parties. The ANC was the most popular amongst the youth vote accounting for $59 \%$ of their vote. While support for the the DA and EFF was almost the same, $11 \%$ and $12 \%$ respectively, $18 \%$ of Black African youth voted for a party outside of the two main opposition parties. While the ANC is clearly the most popular party amongst Black 
African youth, it does appear that young Black African people may be more likely to cast a vote outside of the two main opposition parties.

Figure 2: Percentage of votes going to the top three parties, South Africa LGE 2021

(reporting the University of Johannesburg Centre for Social Change 2021 Election Survey data)

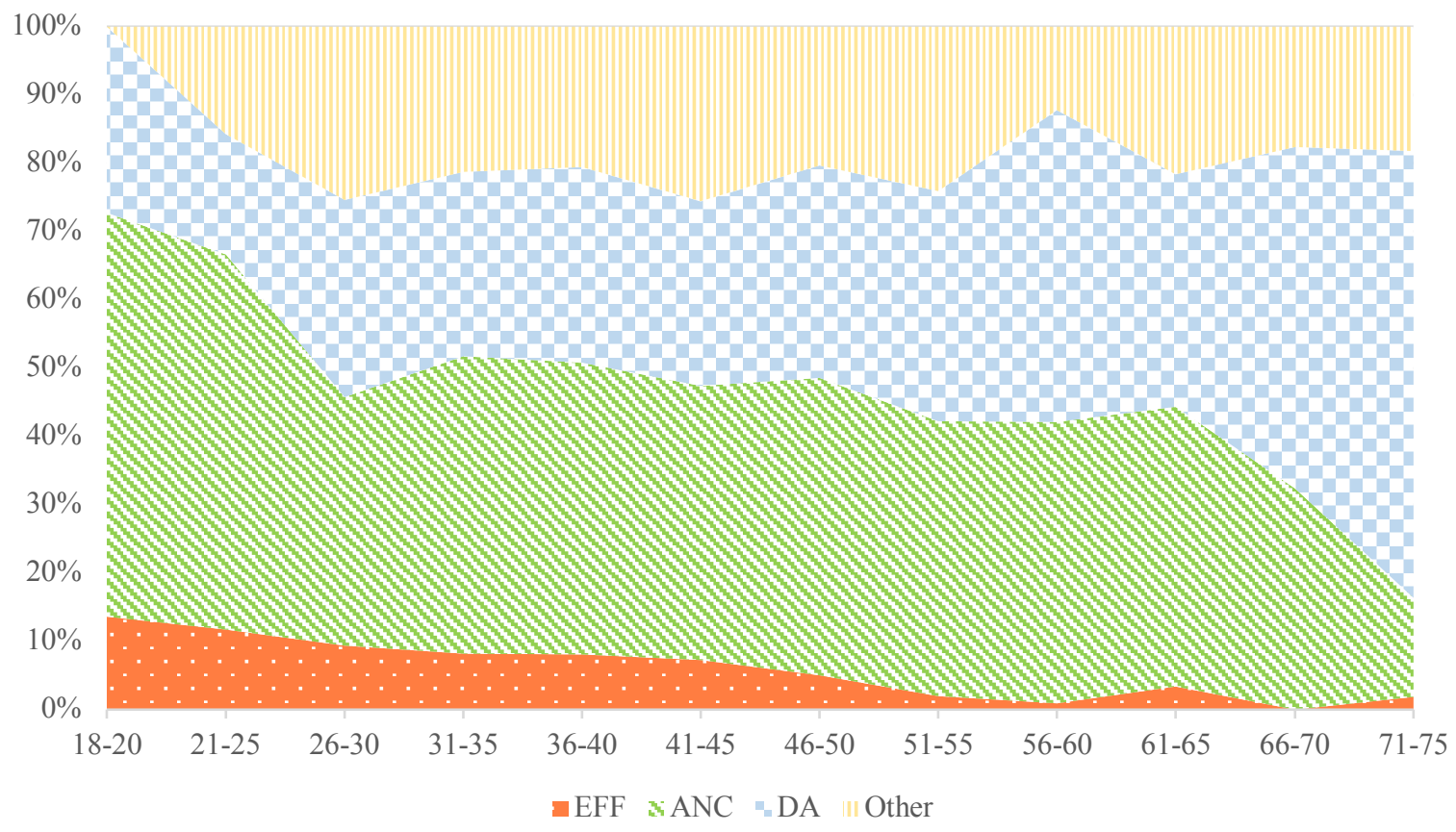

Note: The figure above omits all answers but those reporting support for the largest three parties (including 'refuse to answer' responses)

Amongst Coloured and Indian or Asian youth voters, the DA was the most popular party, attaining 48\% and $67 \%$, respectively, of the vote. Coloured youth also had the highest proportion of support for parties outside the main three parties. The EFF drew minimal support from among Coloured youth and no votes from the Indian and Asian or White youth in our sample. The DA was overwhelmingly the most popular party amongst White youth with the ANC only receiving $3 \%$ of their votes within this sample.

Analysing the youth vote by self-reported gender reveals some gendered differences in party support. Support for the ANC was broadly the same among men and women. The DA enjoyed slightly more support among female youth voters than men, $30 \%$ compared to $24 \%$. Young men voted for the EFF at double the proportion of women, $12 \%$ compared to $6 \%$.

Among employed youth in our sample, support for the ANC and the DA was equally shared, 34\% respectively. Support for the EFF was lowest amongst employed youth (7\%) and highest among students (19\%). The ANC was the most popular party among unemployed youth, attracting $61 \%$ of their votes compared to $15 \%$ for the DA and $10 \%$ for the EFF. 
Table 2: Political party voted for in the 2021 LGE by those aged 18-35 by selected sociodemographic characteristics

\begin{tabular}{|c|c|c|c|c|c|}
\hline \multirow{6}{*}{ Race } & & \multicolumn{4}{|c|}{ Percentages } \\
\hline & \multirow[b]{2}{*}{ Black A frican } & \multirow{2}{*}{$\begin{array}{l}\text { ANC } \\
59\end{array}$} & \multirow{2}{*}{$\frac{\mathrm{DA}}{11}$} & \multirow{2}{*}{$\frac{\text { EFF }}{12}$} & \multirow{2}{*}{$\begin{array}{l}\text { Other } \\
18\end{array}$} \\
\hline & & & & & \\
\hline & Coloured & 13 & 48 & 3 & 37 \\
\hline & Indian or Asian & 14 & 67 & 0 & 19 \\
\hline & White & 3 & 76 & 0 & 21 \\
\hline \multirow[t]{2}{*}{ Gender } & Male & 43 & 24 & 12 & 22 \\
\hline & Female & 45 & 30 & 6 & 19 \\
\hline \multirow[t]{3}{*}{ Employment } & Employed & 34 & 34 & 7 & 25 \\
\hline & Unemployed & 61 & 15 & 10 & 14 \\
\hline & Student & 41 & 22 & 19 & 19 \\
\hline \multirow[t]{3}{*}{ Education } & Less than matric & 56 & 18 & 11 & 15 \\
\hline & Completed matric & 50 & 24 & 11 & 15 \\
\hline & Tertiary education & 33 & 33 & 7 & 28 \\
\hline \multirow[t]{6}{*}{ Accommodation type } & Township or RDP house & 60 & 15 & 8 & 17 \\
\hline & Backyard room & 52 & 19 & 10 & 19 \\
\hline & Informal settlement & 62 & 8 & 14 & 16 \\
\hline & Suburban house & 21 & 48 & 5 & 27 \\
\hline & Flat, apartment or townhouse & 26 & 38 & 11 & 25 \\
\hline & Other & 73 & 9 & 9 & 9 \\
\hline \multirow[t]{7}{*}{ Income } & Less than R1,000 per month & 64 & 14 & 11 & 12 \\
\hline & Between R1,001 and R2,500 per month & 57 & 19 & 9 & 15 \\
\hline & Between R2,501 and R5,000 per month & 64 & 16 & 6 & 14 \\
\hline & Between R5,001 and R10,000 per month & 40 & 26 & 8 & 26 \\
\hline & Between R10,001 and R20,000 per month & 22 & 46 & 7 & 25 \\
\hline & Between R20,001 and R40,000 per month & 22 & 49 & 5 & 24 \\
\hline & More than R40,000 per month & 10 & 52 & 13 & 26 \\
\hline
\end{tabular}

Education also appears to shape party support among the youth. For instance, amongst those without a tertiary qualification (post-secondary or higher education), the ANC was the most popular party, winning more than half of the votes. Among those with a tertiary qualification, a third voted for the ANC and a third voted for the DA, while there was also a high level of support, $28 \%$, for other parties. Support for the EFF was higher among those with matric and less than matric. 
The class basis of the youth vote also becomes apparent in the analysis of youth voting choices by accommodation type and income. The ANC was the most popular party among the youth living in township and RDP houses, backyard rooms and informal settlements, whereas the DA was the most popular among youth living in suburban houses and flats, apartments and townhouses. The highest level of support for the EFF was found among youth living in informal settlements, followed by youth living in flats, apartments or townhouses. This analysis, when combined with an analysis of income, suggests that the EFF splits its vote among working class and middle-class youth.

When analysing the youth vote by income, we see that as income rises support for the ANC declines. Almost two thirds (64\%) of youth earning under R1,0000 per month voted for the ANC in our sample compared to $10 \%$ of those earning over R40,000 per month. The opposite is true of the DA, whereas income rises support among the youth vote increases. About half (52\%) of those earning R40,000 per month voted for the DA compared to $14 \%$ of those earning less than R1,000 per month. For the EFF, the highest levels of support occurred at either end of the income scale. Thirteen percent of those earning more than R40,000 per month and $11 \%$ of those earning less than $1 \%$ per month voted for the EFF. Support for other parties also appears to increase with income suggesting that middle class youth are also increasingly looking outside the three main parties when it comes to casting their vote.

\section{Reasons for youth voter abstention}

As we know from the registration figures provided by the IEC, most young people do not register to vote, nor vote. Why might this be the so? In our survey, participants explained in their own words why they chose not to vote in the 2021 LGE. These reasons were then coded thematically using one of six

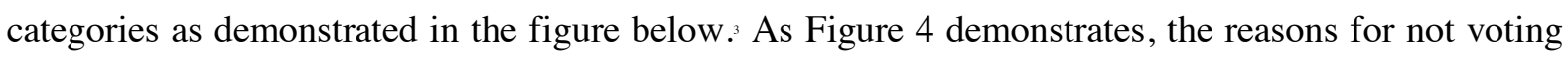
among young voters differs little from that of older voters. Individual barriers, such as not being in their registered ward on Election day, being at work, or saying they were simply 'too busy' to vote, was the most common explanation amongst both the under $35 \mathrm{~s}$ and over $35 \mathrm{~s}$.

Administrative barriers, such as not being registered to vote, was the second most common reason for not voting, accounting for $25 \%$ of the explanations of those aged under 35 and $21 \%$ of those aged over 25.

Reporting being uninterested and disillusioned from voting was reported by 17\% of 18-34 year olds and the over 35s. Performance evaluations, that is, reasons related to poor service delivery and perceived lack of change, seemed to influence the decision not to vote marginally more for the over $35 \mathrm{~s}$ compared to the under 35s. Finally, the lack of political alignment accounted for $5 \%$ of the explanations provided by the under $35 \mathrm{~s}$ and $4 \%$ of the over $35 \mathrm{~s}$. 
A third of explanations (33\%) within this category were driven by concerns around insufficient changes to people's own personal circumstances or within their community. Another $30 \%$ of performance evaluations cited concerns about poor service delivery as supporting their explanation for not voting.

Figure 3. Explanations for not voting in the 2021 LGE (\%)

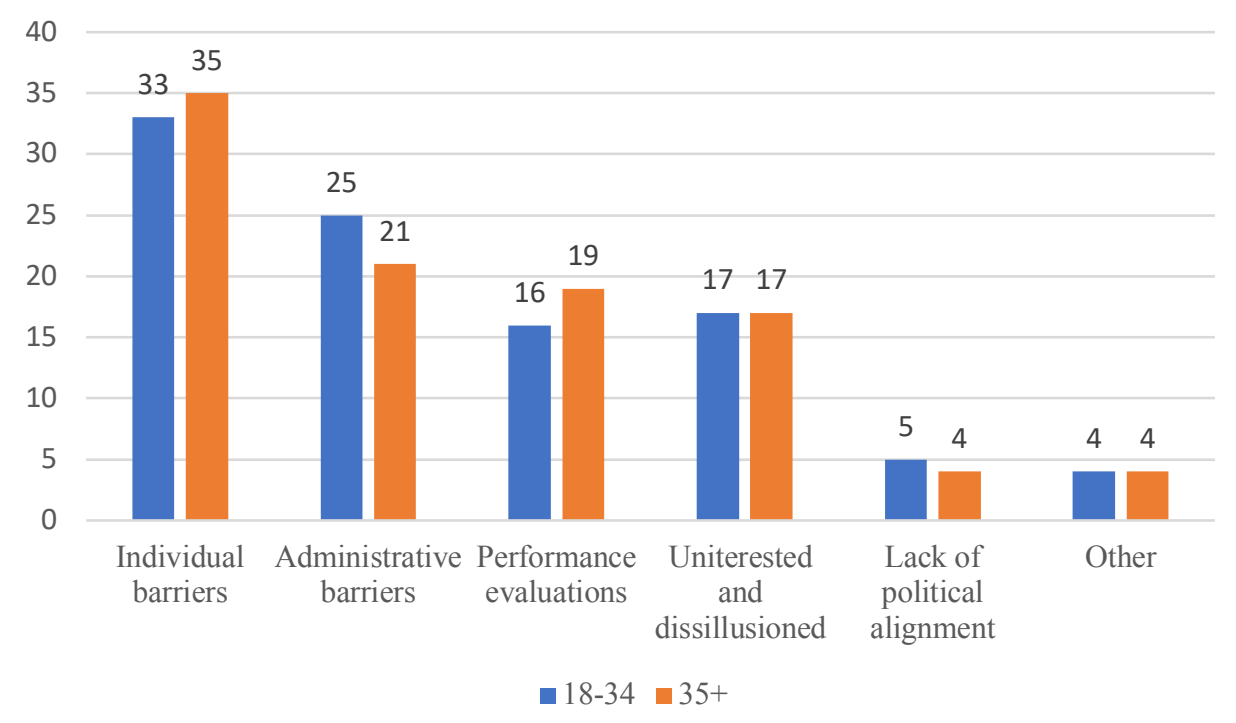

It is interesting to note that the decision by young people not to vote is not substantively different of that from older cohorts. As with older people, youth abstention in the 2021 LGE was largely driven by a combination of individual and administrative barriers. Not registering to vote or being 'too busy' to vote are among the common reasons provided for not voting. Not registering to vote is a pre-emptive disengagement from electoral democracy, one the one hand, while being 'too busy' suggests that participating in electoral democracy is not strongly valued, on the other. Thus, these reasons reflect administrative and individual barriers, but are also suggestive of a different kind of disinterest and disengagement from electoral democracy.

\section{Youth voter fluidity}

The Sankey diagram in Figure 4 helps to visualise the flow of support among parties (and between electoral participation and abstention) at elections since 2016. Ostensibly the most prominent feature is the illustration of broad and sustained non-participation, made manifest in the "Did not vote" stream: about half of our respondents classified as youth did not vote in any of the elections, several of whom are likely not registered for voting. Besides this, the flows confirm our findings about electoral behaviour in South Africa in general - that there is a non-negligible amount of fluidity between voting and abstention, and in the switching of support from one election to another. 
Figure 4: Flow of youth votes between various elections

South African Youth Voter Fluidity 2016-2021

Source: Centre for Social Change, UJ 2021

2016 LGE

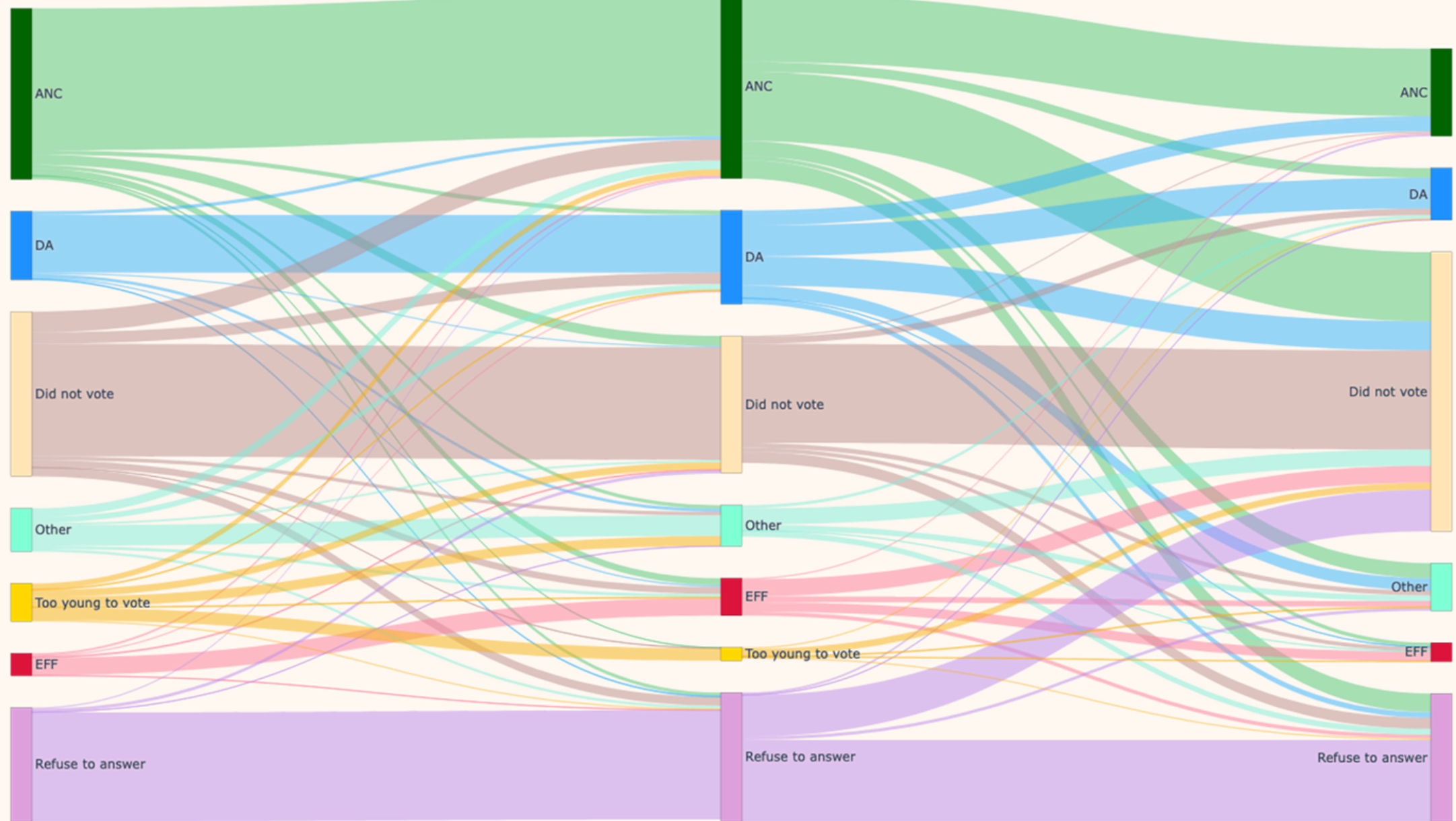


While parties generally receive their support from people who voted for them in the previous election, voters are not consistently party-loyal. Evidence of this is seen in how the ANC cedes votes to the DA and Other parties (especially looking at the flows from 2019 to 2021) but also towards former supporters not voting in 2021. Similarly, a significant portion of DA voters (in 2019) voted for the ANC or not at all in 2021. As is widely reported elsewhere, the DA appears to be the biggest loser of support between 2019 and 2021. Starkly, more respondents who voted for the EFF in 2019 did not vote in 2021 than vote again for the EFF, while several also gave their vote to smaller ("Other") parties. Thus, we confirm the trend of the EFF maintaining support, while not retaining the same voters, from one election to the next, as identified in our 2021 report. ${ }^{6}$ There appears also to be a measure of ideological flow - while there is some movement from the ANC to the EFF (from 2016 to 2019, and from 2019 to 2021), the reverse is not true; by our data, former EFF voters tend to either vote for alternative options ("Other"), or not at all. Of course, the apparently poor voter retention in evidence among all parties may also be related to people voting differently in LGEs than in National Elections.

Among those who were "too young to vote" in 2016 but eligible in 2019, a sizeable amount supported smaller parties. However, Figure 4 also confirms that, of those "too young to vote" in 2019 but eligible to do so in 2021 , the majority decided not to vote.

Table 3: Measures of sustained party support across the 2016 and 2021 LGEs among South African youth

\begin{tabular}{lc}
\hline & $\begin{array}{c}\text { Percentage of 2021 support by voters } \\
\text { who voted for another party in } 2016\end{array}$ \\
\cline { 2 - 2 } ANC & $4 \%$ \\
DA & $24 \%$ \\
EFF & $35 \%$ \\
Other & $56 \%$ \\
\hline
\end{tabular}

The analysis of flows of voter preferences does not mean that party-loyalty is a defunct notion in South African politics. Instead, different parties retain their votes to significantly varied degrees. Table 3 illustrates this by reporting the percentage of each parties' 2021 voters (among youth) that voted for another party (thus, the DA, EFF or "Other", and thus excluding "Too young to vote", "did not vote" or refusals) in 2016, the previous LGE. Here we note that only 4\% of ANC "youth" voters cast their ballot for another party in 2016. This might be contrasted with the DA and EFF, where respectively $24 \%$ and $35 \%$ of their 2021 voters had supported another party in 2016. Regarding the shifting of support between LGE, the most significant changes are seen among voters for smaller parties 
(including, notably, the newly formed "Action SA"), where over half of their 2021 votes came from voters whom had voted for the ANC, DA or EFF in 2016.

\section{Conclusion}

As the 'born-free' generation became eligible to vote there has been an increasing focus on the electoral participation or non-participation of young people. This report has reflected the trends in youth voting in five metropolitan municipalities. Among those who voted, we note high and sustained support for the ANC among young voters, notwithstanding a slight rise of support for the EFF. We found that the proportion of DA votes increase with age, the EFF's decrease with age, and the ANC remains roughly constant (but also decrease with age, as indicated in our sample), while slowing leaking support to the left and the right, echoes the findings of scholars' at the 2019 national election. Furthermore, we observed racialised and classed patterns of voting. Young Black African voters mostly voted for the ANC while White, Coloured and Indian and Asian young voters mostly voted for the DA. Lower income groups had higher share of support for the ANC and the DA drew more of its votes from higher income groups. EFF supporters drew predominately their support from either end of the income scale, with their support concentrated in the lowest and highest income brackets.

The report also analysed the reasons for voter abstention among young people. It found that their reasons for abstention were not distinct from that of older age cohorts. Abstention was largely driven by individual and administrative barriers, accounting for over half of the explanations for voting among the youth voters in our sample. As noted in our previous analysis of voter abstention, ${ }^{8}$ not registering to vote is a pre-emptive disengagement from democracy. High levels of non-registration among the youth are of concern. More research is needed to better understand why young people are increasingly disengaging from electoral democracy.

However, as this report has highlighted abstention is not a static phenomenon. Like older voters, our analysis demonstrates the extent to which the South African electorate is increasingly being marked by voter fluidity - moving between voting and not voting, and switching party political support. While no party retains all their support, especially not between Local Government and National elections, the ANC appears to have more of their support coming from voters who might be considered loyal (i.e. having also voted from the ANC in 2016). On the contrary, the EFF appears to gain and lose almost an equal number of voters across various elections, indicating a measure of party dissatisfaction within our sample. 
Stepping back, we recall how commentators have prophesied about the ANC's day of reckoning in $2021^{1,0}, 2019^{11,2}, 2016^{13}, 2014^{14}$ and 2012 $2^{15}$, a day that has been, once again, postponed. Support for the ANC, as expressed at the 2021 elections, remains double the size of their nearest opposition, meaning that, even if support at the next national election is also below 50\% (which is not a given), it is likely to maintain more than $50 \%$ by going into partnership with a minor party. However, reflecting on 2021's elections, both the low turnout (which first-time voters exemplified in the 2021 polls) and, to a much lesser extent, their willingness to cast their lot with other parties, signals a message of limited loyalty towards the governing party, the ANC. Yet strong support for opposition parties has yet to emerge with many people opting not to vote and thus disengage from an essential participative element of democratic governance. If the choices of first-time voters help suggest the shape of things to come, the mediumterm future of South Africa will entail cross-party coalitions and, ideally, attempts to rekindle trust in participative democracy.

\footnotetext{
${ }^{1}$ https://www.elections.org.za/pw/StatsData/Voter-Registration-Statistics

2 Runciman, C., Paret, M., Bekker, M. and Mbeche, C. (2021) Survey of voters and non-voters in the 2021 local government elections: A methodological brief. Centre for Social Change: University of Johannesburg. Available at https://www.kas.de/documents/261596/10543300/Methods+brief.pdf/23b045d3-4368-ad32-41d678797 dae92da? version $=1.0 \& \mathrm{t}=1638353453174$

${ }^{3}$ A more detailed explanation of how the coding schema was developed can be found in Runciman, C., Bekker, $\mathrm{M}$ and Mbeche, C (2021) Analysing voter abstention in the 2021 local government elections: A view from five metropolitan municipalities. Centre for Social Change, Johannesburg. Available at

https://www.kas.de/en/web/suedafrika/single-title/-/content/analysing-voter-abstention-in-the-2021-localgovernment-elections

${ }^{4}$ Paret, M. and Bekker, M., (2021) Voter fluidity in the 2021 Local Government Elections: Evidence from five metropolitan municipalities. Centre for Social Change, Johannesburg. Available at

https://www.kas.de/en/web/suedafrika/single-title/-/content/voter-fluidity-in-the-2021-local-governmentelections

${ }^{5} \mathrm{https://www.dailymaverick.co.za/article/2021-11-12-the-da-better-or-worse-than-expected/}$

${ }^{6}$ See note 4 above.

${ }^{7}$ Runciman, C., Bekker, M. and Maggott, T., (2019). Voting preferences of protesters and non-protesters in three South African Elections (2014-2019): Revisiting the 'Ballot and the Brick'. Politikon, 46(4), pp.390-410.

${ }^{8}$ See note 3 above.

${ }^{9} \mathrm{https}: / / \mathrm{www}$.iol.co.za/news/politics/opinion/april-27-day-of-political-reckoning-for-anc-nec-2db635e3-3dca4456-9b5e-ece5a2826514

${ }^{10} \mathrm{https} / / \mathrm{www}$.dailymaverick.co.za/article/2021-11-14-the-ancs-mid-term-reckoning/

11 https://www.rfi.fr/en/africa/20190508-ramaphosa-faces-day-reckoning-anc-south-african-election

$12 \mathrm{https} / / / \mathrm{www}$.washingtonpost.com/world/africa/most-south-africans-are-unhappy-with-their-democracy-cancyril-ramaphosa-fix-it/2019/05/06/02040e64-6b95-11e9-bbe7-1c798fb80536 story.html

${ }^{13} \mathrm{https}$ ://www.bloomberg.com/news/articles/2016-07-31/day-of-reckoning-for-anc-as-south-africa-elects-localcouncils

${ }^{14} \mathrm{https} / / \mathrm{bit} .1 \mathrm{y} / 3 \mathrm{FRHLFv}$

${ }^{15} \mathrm{https} / / / \mathrm{www} \cdot$ reuters.com/article/safrica-secrecy/update-2-south-africa-passes-secrets-bill-media-furiousidUSL5E7MM30L20111122
} 